\title{
A NORMALIZAÇÃO DO ESTADO DE EXCEÇÃO NA PANDEMIA CORONAVÍRUS
}

\author{
THE NORMALIZATION OF THE STATE OF EXCEPTION IN CORONAVIRUS \\ PANDEMIC
}

\section{NORMALIZACIÓN DEL ESTADO DE EXCEPCIÓN EN PANDEMIA CORONAVIRUS}

\author{
ViníCIO CARRILHO MARTINEZ \\ https://orcid.org/0000-0002-0593-0544 / http://lattes.cnpq.br/7916014556126573 / vicama@uol.com.br \\ Universidade Federal de São Carlos (UFSCar)
}

São Carlos, SP, Brasil.

https://orcid.org/0000-0003-3671-3822 / http://lattes.cnpq.br/1721329870636878 / vinnyscherch@hotmail.com

Universidade Estadual do Norte do Paraná (UENP)

Universidade Norte do Paraná (UNOPAR)

Londrina, PR, Brasil.

\begin{abstract}
RESUMO
No texto é feita uma análise da situação da pandemia, em suas implicações e desdobramentos sobre a política. Especialmente é analisado como ocorre a utilização do Estado de Exceção como técnica de tentativa de superação das crises. A partir de situações ocorridas no Estado brasileiro em 2020, é feita a leitura da normalização do Estado de Exceção e do Kaiserpresidencialismo. A discussão teórica gira em torno dos argumentos crítico-marxistas para a leitura da crise sanitária, política e de Estado. O texto utiliza o método indutivo e a pesquisa bibliográfica para chegar à conclusão de que a violência institucionalizada pelo Direito pode ser usada de maneira imprópria como técnica para superação dos problemas da sociedade, suplantando o Estado de Democrático de Direito.
\end{abstract}

Palavras-chave: Cesarismo; Estado de Exceção; Kaiserpresidente; Pandemia.

\section{ABSTRACT}

In the text, an analysis is made of the pandemic situation, its implications and developments on politics. Especially it is analyzed how the State of Exception is used as a technique to try to overcome crises. Based on situations that occurred in the Brazilian State in 2020, the normalization of the State of Exception and Kaiserpresidentialism is read. The theoretical discussion revolves around the critical-Marxist arguments for reading the health, political and state crisis. The text uses the inductive method and bibliographic research to come to the conclusion that violence institutionalized by law can be used improperly as a technique to overcome society's problems, supplanting the Democratic State of Law.

Keywords: Caesarism; State of Exception; Kaiserpresident; Pandemic.

\section{RESUMEN}

En el texto, se hace un análisis de la situación de la pandemia, sus implicaciones y desarrollos en la política. Especialmente se analiza cómo se usa el Estado de excepción como una técnica para tratar de superar las crisis. En base a situaciones que ocurrieron en el Estado brasileño en 2020, se lee la normalización del Estado de excepción y el Kaiserpresidencialismo. La discusión teórica gira en torno a los argumentos crítico-marxistas para leer la crisis sanitaria, política y estatal. El texto utiliza el método inductivo y la investigación bibliográfica para llegar a la conclusión de que la violencia institucionalizada por la ley puede usarse de manera inadecuada como una técnica para superar los problemas de la sociedad, suplantando el Estado de derecho democrático.

Palabras-clave: Cesarismo; Estado de excepción; Kaiserpresident; Pandemia. 


\section{SUMÁRIO}

INTRODUÇÃO; 1 CESARISMO DE ESTADO (A PARTIR DE GRAMSCI); 2 KAISERPRESIDENTE EM WEBER; 3 A EXCEÇÃO NO SÉCULO XXI; 4 O NÃO-DIREITO COMO MEIO DE EXCEÇÃO; 5 O BANÓTICO NORMALIZOU A EXCEÇÃO; CONCLUSÃO; REFERÊNCIAS.

\section{INTRODUÇÃO}

Lembremos, primeiramente, que normalização - no âmbito do Estado Moderno equivale à normatização ou à ideia do Direito como ficção (ideário): onde há lei, a vida social está pacificada. No entanto, no século XXI não é disso que se trata, ou não é só disso, visto que o terrorismo, as sedições, as crises econômicas, a fome, o descontrole ambiental, as pandemias, a falta de capacidade técnica ${ }^{1}$, ou seja, qualquer coisa, tudo pode ser a motivação à decretação de Estado de Exceção - seja na forma de Estado de Sítio, Estado de Emergência ${ }^{2}$ ou aplicação de Lei Marcial. Em alguns casos, pode-se dizer que são exemplos notórios de não-Estado ${ }^{3}$, em outros são casos de Estado de não-Direito ${ }^{4}$ ou se ajustam como golpes de Estado, quarteladas, “intervenções militares” e Ditaduras Inconstitucionais ${ }^{5}$.

\footnotetext{
${ }^{1}$ A partir 07 de abril de 2020 , as mensagens que forem altamente replicadas poderão ser encaminhadas para apenas uma pessoa, grupo ou lista de transmissão de cada vez. A medida visa restringir a capacidade de propagação de informações falsas pelo WhatsApp, algo que virou um problema nos últimos anos e é mais preocupante agora que o mundo enfrenta a pandemia do novo coronavírus (GOMES, Helton Simões. Um contato de cada vez! WhatsApp impõe novo limite para encaminhar mensagem. Uol, São Paulo, 7 abr. 2020. Disponível em: https://www.uol.com.br/tilt/noticias/redacao/2020/04/07/um-contato-de-cadavez-whatsapp-impoe-novo-limite-para-encaminhar-

mensagem.htm?utm_source=chrome\&utm_medium=webalert\&utm_campaign=tilt\&fbclid=IwAR2OQlIKbkO WgvYvvVIt6Tif4m10jzEY_c1jGc2jPcNBOjb4D8XwWHxoUs. Acesso em: 8 abr. 2020).

${ }^{2}$ Dominique Rousseau faz o apontamento de que o Estado de Emergência, da maneira como vem sendo utilizado por governos em geral por conta da COVID-19, pode acabar se tornando em instrumento ordinário de administração das situações, o que põe em risco uma série de direitos que se tornam suspensos nesse período e torna factível o exercício arbitrário do poder (ROUSSEAU, Dominique. França: Os estados de emergência e os perigos de uma nova normalidade. Estadão, 28 mar. 2020. Disponivel em: https: / /estadodaarte.estadao.com.br/franca-os-estados-de-emergencia-e-os-perigos-de-uma-novanormalidade/?fbclid=IwAR0lgmnjEQpDo7pe96w4oR6xEgde-OhMQl_eAS0gD6txNgjY9AnH7SJhvlk. Acesso em: 6 abr. 2020).

${ }^{3}$ BOBBIO, Norberto. Estado, governo, sociedade: para uma teoria geral da política. 3. ed. Rio de Janeiro: Paz e Terra, 1987. p. 121-123.

${ }^{4}$ MARTINEZ, Vinício Carrilho. Teorias do Estado: Estado de (Não) Direito: quando há negação da Justiça Social, da democracia popular, dos direitos humanos. São Paulo: Scortecci, 2014.

${ }^{5}$ MARTINEZ, Vinício Carrilho. Teorias do Estado - Ditadura Inconstitucional: golpe de Estado de 2016, forma-Estado, Tipologias do Estado de Exceção, nomologia da ditadura inconstitucional. Curitiba: CRV, 2019b.
} 
Neste século parece ter se introjetado, de modo definitivo, uma lei de eterno retorno à exceção, com a crescente substituição da regra pela violência da regra. Como se a Força da Lei não fosse mais o objetivo, mas sim a violência que todo Direito congrega - não há dúvidas de que a exceção, como regra, e esta é a marca indelével do século XXI, comprova a etimologia no dito de que não é a força no sentido de poder, mas sim a violência a consagrar o Direito ab origine ou direito natural ${ }^{6}$. No Estado de Exceção se emprega a violência contida no Direito - dado que originária (Gewalt) - a fim de se anular a própria força política, se entendermos como a Política do espaço público democrático e emancipatório ${ }^{7}$.

No Estado de Exceção, trata-se do uso/abuso da força (poder) como extensão da violência - o Direito como negação da Política -, a fim de que o Poder Austero, Poder Político autocrático inerente ao perfil do Kaiser presidente, afirme-se como vontade do Poder Público. Neste sentido, confundem-se, entrelaçam-se, Poder Público e Razão de Estado personificada (justificativa para usar, abusivamente, da força). Neste Staatsgewalt (poder abusivo do Estado, como estágio primário), a potestas revela-se como vis: a violência do poder nu, sem mediações, sem que o Direito reflua a violência como medium.

O Estado de Exceção reporta imposições político-jurídicas - aliás, antes são políticas e, só em derivação, tornam-se forçosamente jurídicas - que em muitos aspectos relembram Emile Zola ou o Caso Dreyfus: Judiciário Fake. No espectro político-jurídico mais recente, como exposição máxima da exceptio, o Estado de Sítio nazista, em longevos 12 anos, é um marco. E há lições a retirar desse processo, as quais iremos aqui correlacionar com o estado das coisas atuais na política.

Enfrentar crises, não é uma tarefa simples, pois exige a mobilização de todas as categorias da sociedade e todas as instituições, pressupondo-se um engajamento para atingir o alvo comum de tornar viável a convivência pacífica. A pandemia causada pelo novo coronavírus (COVID-19) demonstra que uma questão sanitária pode repercutir nas mais variadas nuances do tecido social. Quando observamos o impacto global da COVID-19, que desnuda não só a fragilidade biológica do ser humano, mas também a sua falta de habilidade para compreender que estamos em um lugar comum na natureza - salvo a possibilidade de sermos capazes com a própria natureza -, a crise se amplia, já que avança sobre sistemas políticos e econômicos com voracidade. 0 problema com o qual lidamos aqui é justamente esse: a falta de habilidade para

\footnotetext{
${ }^{6}$ BENJAMIN, Walter. Crítica da Violência - Crítica do Poder. In: BOLLE, Willi (Org). Documentos de cultura documentos de barbárie: escritos escolhidos. Tradução Celeste H. M. Ribeiro de Sousa et al. São Paulo: Cultrix, 1986. p.160

${ }^{7}$ ARENDT, Hannah. 0 que é política? Tradução Reinaldo Guarany. 3. ed. Rio de Janeiro: Bertrand Brasil, 2002.
} 
ISSN 1981-3694

(DOI): $10.5902 / 1981369448127$

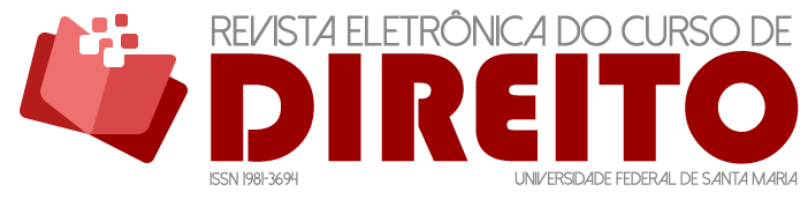

A NORMALIZAÇÃO DO ESTADO DE EXCEÇÃO NA PANDEMIA CORONAVÍRUS

VINÍCIO CARRILHO MARTINEZ VINÍCIUS ALVES SCHERCH

organizar a sociedade e a tendência à adoção dos regimes de exceção para tentar contornar a crise. E sempre que surge um problema que demanda a solução do imprevisível ou do incalculável, a humanidade parece adotar uma conduta tangencial, instituindo medidas de exceção.

A partir desse problema apresentado, qual seja, a aparente inoperância do Direito em face da atuação política negativa - que corrobora no uso dos instrumentos institucionais para a naturalização da violência - a hipótese de trabalho que adotamos fundamenta-se no fato de que o Estado de Direito Democrático não é respeitado como deveria ser pelos governos, pois ante qualquer ameaça que fuja do padrão de controle, surge a alternativa do Estado de Exceção como técnica de governo, deteriorando-se o processo civilizatório. Dessa forma o objetivo do artigo é, dentro do corpus crítico-marxista, correlacionar a exceção como técnica de governabilidade, que no contexto da pandemia, eclipsa o processo civilizatório.

Como metodologia de elaboração do manuscrito, adotamos o método indutivo que sai da conjuntura específica da pandemia para o âmbito geral das Teorias de Estado e, com relação ao tipo da pesquisa, é bibliográfico, porque vem pautado na literatura existente sobre o tema aqui tratado. A estruturação do artigo segue cinco eixos que se comunicam para apontar a trajetória do cesarismo ao Kaiserpresidente, pela prática da normalização da exceção, aproveitando-se da pandemia para pôr em prática a técnica autoritária de governabilidade.

\section{CESARISMO DE ESTADO (A PARTIR DE GRAMSCI)}

Por analogia, o que o pensamento gramsciano definiu como cesarismo parlamentar assente no Parlamentarismo, porque o compromisso típico do cesarismo é possível em nível parlamentar, a partir dos governos de coalizão ${ }^{8}$ - redesignamos como Cesarismo de Estado, na conjuntura atual. No chamado capitalismo de coalizão, em nosso caso superpresidencialismo de colisão, a capacidade coercitiva (coalizão de forças de intervenção/repressão) investe na formação de um paradigma sistêmico de triangulação das ordens e do comando: os três poderes instituídos atuariam como César. Ou seja, a ideia de independência e harmonia constante do art. $2^{\circ}$ da Constituição Federal cede ao assédio dos representantes que ocupam o espaço político para sobrepor seus interesses particulares de maneira conjugada nas estruturas de Estado. Independentemente de certos desequilíbrios ou dissonâncias verbais, os três poderes agem em consórcio. Exemplo disso foi o processo de impeachment. Dessa forma, Gramsci apontou

${ }^{8}$ LIGUORI, Guido;VOZA, Pasquale (Org). Dicionário Grasmsciano. São Paulo: Boitempo, 2017. p.110 
características essenciais para a compreensão do cesarismo na prática e sua viabilização por meio das estruturas de poder do Estado:

\begin{abstract}
Pode-se ter "solução cesarista" mesmo sem um César, sem uma grande personalidade "heroica" e representativa. 0 sistema parlamentar forneceu o mecanismo para tais soluções de compromisso [...] Todo governo de coalizão é um grau inicial de cesarismo, que pode ou não se desenvolver até graus mais significativos (naturalmente, a opinião vulgar é a de que, ao contrário, governos de coalizão constituem o mais "sólido baluarte" contra o cesarismo) [...] A técnica política moderna mudou completamente após 1848 , após a expansão do parlamentarismo, do regime associativo sindical e partidário [...] Neste sentido, inteiros partidos "políticos" e outras organizações econômicas ou de outro gênero devem ser considerados organismos de polícia política, de caráter investigativo e preventivo. ${ }^{9}$ (grifo nosso)
\end{abstract}

Apesar de Gramsci salientar o Parlamentarismo - como sistema de governo - não nos parece avocar uma interpretação restritiva, isto é, desmerecedora do Presidencialismo como lócus da exceção. Isso porque o cesarismo sempre expressa a solução arbitrária, que é confiada a uma grande personalidade, de uma situação histórico-política determinada, caracterizada por um equilíbrio de forças de perspectiva catastrófica, que nem sempre tem o mesmo significado histórico. Essa capacidade de centralização de forças, obviamente, é muito maior no presidencialismo. Dessa forma, Gramsci afirma que pode haver um cesarismo do tipo progressivo e um cesarismo do tipo regressivo; cujo significado exato de cada um desses tipos pode, em última instância, ser reconstruído pela história concreta e não pelo esquema sociológico. Surge o cesarismo progressivo quando sua intervenção ajuda as forças progressistas a triunfar, mesmo com certos compromissos e limitações da vitória, ao passo que é regressivo quando sua intervenção ajuda a triunfar forças regressivas ${ }^{10}$.

Sob o condão do cesarismo, não é de supor, portanto, que ao destacar o Parlamentarismo, como eixo do cesarismo parlamentar, Gramsci queira desqualificar o Presidencialismo como orquestra do cesarismo: “assim, o estudo do regime presidencial americano (Estados Unidos da América), com sua unidade entre chefe de Governo e chefe de Estado [...] é semelhante ao regime das repúblicas comunais medievais italianas (fase econômico-corporativa do Estado)"11. Inclusive porque a dinâmica do sistema de poder

\footnotetext{
${ }^{9}$ GRAMSCI, Antonio. Cadernos do cárcere. Rio de Janeiro: Civilização Brasileira, 2000. (Org. Carlos Nelson Coutinho). p. 77-78

${ }^{10} \mathrm{GRAMSCl}$, Antonio. Notas sobre Maquiavelo, sobre la politica y sobre el Estado moderno. Traducción y notas: José Arieó. Madrid: Neueva Visión, 1980. p.71

11 GRAMSCI, Antonio. Cadernos do cárcere. Rio de Janeiro: Civilização Brasileira, 2000. (Org. Carlos Nelson Coutinho). p. 299
} 
presidencialista, muito mais centralizado e avesso à conclamação de soluções negociadas para as crises, é muito mais efetiva do que no Parlamentarismo. A Itália de Mussolini e a Alemanha de Hitler (Kaiserpräsident) são casos concretos.

No Cesarismo de Estado ou parlamentar, a dosagem de manu militari - a exemplo da Intervenção Federal na segurança do Rio de Janeiro - decorre de anuência explícita do denominado monopólio legítimo do uso da força física (violência institucional). Age com tutela e domínio sobre os aparatos de Estado destinados ao controle social (suma potestas). Ou seja, o cesarismo tradicional (Bismarck) ou o cesarismo parlamentar (de Estado) resulta diretamente da dominação racional-legal: com notável aplicação da burocracia judicial a reforçar o status quo.

Nesse âmbito do cesarismo, podemos verificar que sua incidência se dá de uma maneira ampla e irrestrita sob o monopólio do poder de império - que o Estado exerce unilateralmente, com presunção de legalidade e autoexecutoriedade -, porém sem buscar a tutela do interesse público, uma vez que o aparato de Estado é manejado para o interesse da autoridade detentora do poder ou do grupo dominante. De qualquer forma, o cesarismo se apresenta como ruptura dos valores protegidos pelo Direito quando o povo - enquanto sujeito ativo e participante - é subtraído das fórmulas políticas de decisão.

Por isso, pode-se dizer que - diferentemente de outros tempos, em que se podia decidir contramajoritariamente - hoje vivenciamos uma espécie de bonapartismo regressivo (tal qual Luís Bonaparte) em que ocorrem mudanças qualitativas dentro do Poder Político: do Estado Social ao neocolonialismo. Essa figura, em espécie, pode ser inserida no estudo do cesarismo:

O bonapartismo seria a forma-Estado burguesa do cesarismo, com condições e funções mais precisas ao desenvolvimento do capital hegemonizado financeiramente. Em ambas as formas, ainda que em aparência vigorem instituições políticas essenciais à República, há evidente contra facção da liberdade política. Quando se admitem formas de representação popular há o uso recorrente do aparato policial. 0 diálogo com as massas é manipulado, populista, demagógico e abastecido de culto à personalidade, utilizando-se de formas variadas de propaganda política. 0 líder é considerado a própria encarnação da soberania una e indivisível - e seu poder, obviamente, inquestionável. ${ }^{12}$

Também atendendo por cesarismo regressivo, agudizam-se forças repressivas (militarização das relações sociais) e regressivas: ao status quo ante (antes da Constituição

\footnotetext{
12 MARTINEZ, Vinício Carrilho; SCHERCH, Vinícius Alves. Do bonapartismo à intervenção federal. Revista Jus Navigandi, Teresina, v. 23, n. 5433, maio 2018. ISSN 1518-4862. Disponível em: https://jus.com.br/artigos/64558. Acesso em: 17 abr. 2020. Também: MARTINEZ, Vinício Carrilho; SCHERCH, Vinícius Alves. Do bonapartismo à intervenção federal. Gente de Opinião, 4 mar. 2018. Disponível em: https://www.gentedeopiniao.com.br/colunista/vinicio-carrilho/do-bonapartismo-aintervencao-federal-por-vinicio-martinez-e-vinicius-scherch. Acesso em: 16 mai. 2021.
} 
ISSN 1981-3694

(DOI): $10.5902 / 1981369448127$

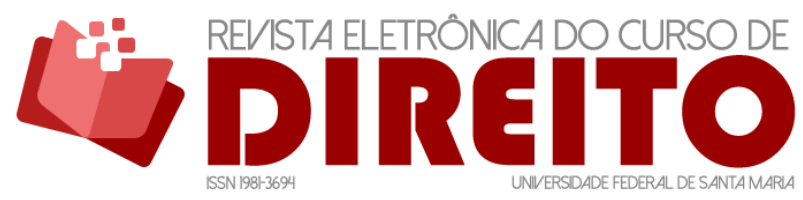

A NORMALIZAÇÃO DO ESTADO DE EXCEÇÃO NA PANDEMIA CORONAVÍRUS

VINÍCIO CARRILHO MARTINEZ VINÍCIUS ALVES SCHERCH

Federal de 1988). Se até 2016 queixava-se da contaminação trazida pela criminalização das relações sociais, em 2018 é evidente a militarização das relações sociais e políticas. A segurança pública não só é tomada em equivalência da segurança nacional, como em seu comando maior está um general do exército. Este conjunto aceso de adoção judicial, das polícias e do manu militari, do Legislativo submisso ao Executivo, promove mudanças quantitativas na democracia e qualitativas na exceptio: com o crescente uso/sistêmico dos meios de exceção. Este seria o trinômio do cesarismo regressivo e repressivo.

\section{KAISERPRESIDENTE EM WEBER}

A figura jurídica de exceção, concentradora de superpoderes, do Kaiserpräsident foi estampada no art. 48 da Constituição de Weimar (1919) e permitiu todo poder ao Füher. Essa mistura de parlamentarismo sem Parlamento, sem presidencialismo plebiscitário, e dotado de poderes de exceção, fez do Kaiser presidente um tipo ideal para golpistas.

Este Kaiser presidente - como uma forma "modernizada" de Monarquia (In)constitucional - teria origem conceitual na realidade da própria Alemanha: unificada por Bismarck. Além de poderes excepcionais, o Kaiser presidente tem muito carisma: daquele tipo religioso, Salvador da Pátria, de modo peculiar confundindo seus interesses particulares no interesse da população e se aproveitando de um viés populista para legitimar sua atuação. E nisto se distância do "homem de virtù", o Príncipe de Maquiavel que deveria comprovar "valor" político e não se aproveitar, meramente, da coerção disponível; pois, é a virtù ("virtudes" como “valor" político) quem desloca e controla o "furor”, a violência e a coerção.

Para fins de comparação, o Reichspräsident - um tipo ideal anterior ao de Weimar seria uma figura pública com comprovada "experiência" que pudesse dirigir as distopias parlamentares. Este modelo foi levado pelo sociólogo alemão Max Weber à própria feitura da Constituição alemã de 1919. Daí, em subsunção, terminou como Kaiserpräsident. E do Reichstag foi-se ao Reich. A escolha plebiscitária entre os mais "dotados de fazer-política" daria fomento a que sempre surgisse um "novo" Bismarck: um cesarismo, "governo de gênio", na forma revigorada do general romano Caio Júlio César. Em tempos de turbulência só o César pode nos salvar. Um cesarismo por aclamação, portanto. Para Weber, apelo plebiscitário e cesarismo são 
coincidentes em significado: “afinal de contas, a técnica especificamente cesarista é o plebiscito" ${ }^{13}$. Em suas palavras:

O líder cesarista aparece à moda militar como Napoleão I, ditador que teve sua posição confirmada por um plebiscito, ou então aparece à maneira burguesa: mediante confirmação plebiscitária, com aquiescência do Exército, de uma reivindicação ao poder, da parte de um político não-militar, como Napoleão III [...] As circunstâncias do afastamento de Bismarck demonstram a maneira pela qual o legitimismo hereditário das monarquias reage contra esses poderes cesaristas. ${ }^{14}$

Para Weber e os (f)autores da Constituição de Weimar (o empuxo nazista) a democracia de massas é, essencialmente, demagógica. Assim, para corrigir tal imperfeição, o plebiscito deveria levar à escolha de homens de experiência, de gênio ou tino político confirmado. Em geral, “os candidatos são apresentados a eleitores destituídos de capacidade de crítica técnica”" Então, a seleção dos candidatos em listas de homens capazes faria toda a diferença, o que resultaria em um Parlamento de elite técnica e daí sairia outro Bismarck ou um César vocacionado. A Constituição e o governo seriam seus presentes.

Sintomas do cinismo histórico também são apontados nesse procedimento: “A ironia, disse, ‘é o grão de sal que permite que se desfrute do que se põe à mesa”" ${ }^{16}$. Porém, antes disso, o próprio Goethe diria: “Quem está com o direito, espera, e a hora virá”17.

No sintomático Brasil de 2020, observando-se que sequer tivemos uma fase de Monarquia Constitucional - porque fomos do Império à República, e à Constituição de 1891 -, retroagimos a algum tipo de Constituição Autocrática. E pelo caminhar do judice em que se põem o STF e o Congresso Nacional, é ainda possível que nos presenteiem com o Estado Teocrático ${ }^{18}$.Em resumo: teremos um Estado Teocrático com Constituição Autocrática?

A possível resposta advém da própria observação do Direito enquanto um produto exclusivo do Estado Teocrático que ocorre da observância dos bons costumes, das tradições e embebido em uma moralidade que orienta a produção da lei para encerrar o processo de positivação da Constituição Autocrática, com a retirada do processo de construção do Direito e

\footnotetext{
${ }^{13}$ WEBER, Max. Textos selecionados. 3. ed. São Paulo: Abril Cultural, 1985. (Os Pensadores). p. 74.

${ }^{14}$ WEBER, Max. Textos selecionados. 3. ed. São Paulo: Abril Cultural, 1985. (Os Pensadores). p. 74.

${ }^{15}$ WEBER, Max. Textos selecionados. 3. ed. São Paulo: Abril Cultural, 1985. (Os Pensadores). p. 74.

${ }^{16}$ MANN, Thomas. Carlota em Weimar. Rio de Janeiro: Nova Fronteira, 2000. p. 77

17 GOETHE, Johann Wolfgang von. Fausto. Belo Horizonte: Itatiaia, 1997. p. 418

18 MARTINEZ, Vinício Carrilho. O conceito de carta política na CF/88: freios político-jurídicos ao Estado de não-Direito. Pesquisa de Pós-Doutorado em Ciências Jurídicas. Paraná: Universidade Estadual do Norte do Paraná , 2019a.
} 
da Política das mãos do povo, pela dúbia via do populismo que mascara todo esse procedimento. Em poucos instantes da história política mundial retirou-se direitos ao povo e este aplaudiu e ainda empossou o violador de direitos fundamentais.

Assim, se a democracia implica em reconhecer que nem todas as leis já estão escritas e que, por isso, é necessária a inclusão de sujeitos de direitos para buscar um processo qualitativo de Estado e de sociedade, em sentido contrário, quando a política está adstrita à guia de grupos identificáveis - com tendência à restrição das liberdades, desconsideração do outro como sujeito e regressão da razão - há a ambientação para ocorrência do Kaiserpresidente.

\section{A EXCEÇÃO NO SÉCULO XXI}

Do passado ao presente, há um mimetismo que assegura a perpetuação da exceção, não somente enquanto "regra de exceção" prevista constitucionalmente (art. 137 da Constituição Federal), mas, muito mais por não se modificar o próprio miolo de todas as regras: a violência $A b$ origine da regra do Direito é inconteste e incontida ${ }^{19}$. Num exemplo simples, veja-se toda a legislação expansiva dos crimes hediondos e multiplicada no pós-Constituição de 1988. Do presente ao passado, há uma metamorfose, todavia, ocorre como desfiguração ${ }^{20}$, retrogradação, Transmutação Constitucional ${ }^{21}$, que desfigura os seus valores. Ocorre-nos, além da coisificação, efeitos de monstruosidade política e técnica em absoluta aparência de normalidade. Muitos até agradecem porque se sentem mais seguros: "se não fiz nada de errado, nada tenho a esconder, podem vasculhar minha intimidade" ou “o regime só é ruim para quem é bandido". Isso se diz abertamente, a céu aberto.

No Estado de Exceção, a regra é o expurgo. Muito parecido com as redes sociais, em que deletamos, excluímos, bloqueamos o que e quem não nos interessa, só que na vida real e, efetivamente, matando pessoas de verdade - via de regra negros e pobres. Se a comunicação é regra para a Humanidade (desde o grito primal), as redes sociais nos dirigem para o oposto; propositalmente os algoritmos nos direcionam para as semelhanças, para o mesmo discurso,

19 BENJAMIN, Walter. Crítica da Violência - Crítica do Poder. In BOLLE, Willi (Org.). Documentos de cultura. documentos de barbárie: escritos escolhidos. Tradução Celeste H. M. Ribeiro de Sousa et al. São Paulo: Cultrix, 1986. p.163

20 KAFKA, Franz. A metamorfose. São Paulo: Companhia das Letras, 1997.

21 MARTINEZ, Vinício Carrilho; SCHERCH, Vinícius Alves. Mutação ou transmutação constitucional, o tendencionismo à opinião pública como obstáculo aos Direitos Fundamentais. Revista Juris Poiesis, Rio de Janeiro, v. 23, n. 31, abr. 2020, p. 174-196. Disponível em: http://periodicos.estacio.br/index.php/jurispoiesis/article/viewFile/8169/47966748 . Acesso em: 18 set. 2020. https://doi.org/10.5935/2448-0517.20190062. p. 183. 
como se continuamente reforçássemos nossos próprios pensamentos. Desse ponto de vista, as redes sociais, notadamente o Facebook, constroem interatividades a partir da mesmice ${ }^{22}$, aniquilam o contraditório, são abruptamente, constantemente, Ab origine, antidemocráticas. As redes sociais, que se expandiram potencialmente na última década, embora carreguem acessibilidade ao conhecimento e às informações, transportaram também os equivalentes reais de grupos hegemônicos, levando a uma regressão ao estado de massa:

\begin{abstract}
O fenômeno mais típico dessa regressão ao estado de massa é a impossibilidade de se fazer escutar por argumentos ou fatos, além da irrelevância relativa das fontes. No interior de uma batalha discursiva, o uso de fake news, de forma intencional ou ingênua é bastante facilitado. Os interlocutores repetem monólogos com crescente agressividade. A regressão ao funcionamento de massa, com sua estereotipia e certeza dogmática, produziu um extenso sentimento de divisão social, rompendo laços e dissociando relações. ${ }^{23}$
\end{abstract}

As redes sociais, partindo-se desta regra de exclusão (exceção), são desumanizadoras, pois que bloqueiam toda a capacidade de comunicação. Isto é, as redes sociais, ao menos neste princípio, replicaram a tecnicalidade do Estado de Exceção, quando excluir é a regra. Então, não apenas replicamos as técnicas que remontam ao nazi-fascismo, como ainda as tornamos universalizáveis, com o objetivo de estendermos sua comunicação aos sete bilhões de habitantes do planeta. E, mesmo antes disso, tornamos a exclusão um ponto de partida, uma vez que a técnica assim foi planejada, pois, a regra é excluir, bloquear, e só compartilhar o que nos agrada. Por fim, antes mesmo de nos conectarmos, a exceção já nos dirigiu em sua programação excludente, o que, obviamente, torna-a absolutamente normal. Quando o usuário aceita os termos de uso, em $99 \%$ dos casos sem ler, equivale a dizer única e simplesmente que: a exceção, a exclusão, neste meio de uso e de troca, é a regra. E, assim, não apenas como nomologia (normatização dos meios de exceção), mas, sobretudo e diretamente, enquanto meio de comunicação massivo, as redes sociais propagam e incitam à total servidão voluntária ${ }^{24}$ em que há normalização da exceção.

Enfim, é fácil e óbvio verificar que, quem não exclui, sequer é incluído nas redes sociais. Dos Editos dos poderes de César às redes sociais, do século XXI, muita água passou por

22 BAUDRILLARD, Jean. A transparência do Mal: ensaio sobre os fenômenos extremos. Campinas: Papirus, 1990.

23 DUNKER, Christian Ingo Lenz. Psicologia das massas digitais e análise do sujeito democrático. In: ABRANCHES, Sérgio et al. Democracia em risco? 22 ensaios sobre o Brasil de hoje. São Paulo: Companhia das Letras, 2019. p.122.

${ }^{24}$ LA BOÉTIE, Étienne de. Discurso da servidão voluntária ou o contra um. Comentários: Claude Lefort. Pierre Clastres e Marilena Chauí. Tradução Laymert Garcia dos Santos. São Paulo: Brasiliense, 1999. p. 91. 
moinhos solitários ou coletivos, muito mimetismo e metamorfoses foram replicadas, no entanto, estamos a ver uma situação inaudita: as redes sociais aplicam, desde sua programação originária (algoritmos), regras de normalização da exceção. As redes sociais, como complemento do Totalitarismo Digital, na sociedade de controle ${ }^{25}$, são “meios de comunicação" que excluem o princípio da comunicação (contraditório) e se limitam a uma feliz autoexclusão.

Vivemos como "robôs alegres"26, cada um em seu casulo, no banótico de Didier Bigo ${ }^{27}$ que cada dia fala menos. No ambiente de isolamento da vida civil, externa às redes sociais, em face da pandemia do novo coronavírus, esse efeito se multiplicou: temos agora vários banóticos, capazes de mostrar quem é "bem-vindo ou não, criando categorias de pessoas excluídas não apenas de determinado Estado-nação, mas de um conjunto bastante amorfo e não unificado de potências globais" ${ }^{28}$.

As próprias denúncias e possíveis restriçõos globais, à imposição do Estado de Exceção, recebem acompanhamento fragilizado. A opinião pública internacional, talvez seguindo um pouco a dinâmica da Primavera Árabe, pudesse ser melhor estimulada, no plano prático e no virtual. Esta paralisia ocorre por inúmeras razões, dentre as mais graves aflora a normalização (leia-se normatização) dos meios de exceção. Como se operasse uma única regra de exceção, um princípio ativo que inocula todas as tessituras e gramáticas constitucionais, das ditaduras comuns à Guerra Híbrida mais sofisticada ${ }^{29}$. A mesma lógica de subsunção do Direito ao poder é verificada na Ditadura Inconstitucional ${ }^{30}$, posto que, se o Direito não expressa necessariamente um soberano será, obrigatoriamente, expressão do Cesarismo de Estado. Gramsci ${ }^{31}$ falou-nos de um cesarismo parlamentar.

No Estado de Sítio - ainda que conforme uma estrutura jurídica, tratar-se-ia de golpe à Constituição, no dizer de Bonavides ${ }^{32}$, a eliminação física deve ser considerada, em plano de

\footnotetext{
${ }^{25}$ DELEUZE, Gilles. Conversações. Rio de Janeiro: 34, 1992.

${ }^{26}$ MILLS, Charles Wright. A imaginação sociológica. 2. ed. Rio de Janeiro: Zahar, 1969.

${ }^{27}$ BAUMAN, Zygmunt. Vigilância líquida: diálogos com David Lyon. Tradução Carlos Alberto Medeiros. Rio de Janeiro: Zahar, 2013.

${ }^{28}$ BAUMAN, Zygmunt. Vigilância líquida: diálogos com David Lyon. Tradução Carlos Alberto Medeiros. Rio de Janeiro: Zahar, 2013. p.45

29 KORYBKO, Andrew. Guerras Híbridas: das revoluções coloridas aos golpes. São Paulo: Expressão Popular, 2018.

30 MARTINEZ, Vinício Carrilho. Teorias do Estado - Ditadura Inconstitucional: golpe de Estado de 2016, forma-Estado, Tipologias do Estado de Exceção, nomologia da ditadura inconstitucional. Curitiba: CRV, 2019a.

31 GRAMSCI, Antonio. Cadernos do cárcere. Rio de Janeiro: Civilização Brasileira, 2000. (Org. Carlos Nelson Coutinho). p. 77-78

32 BONAVIDES, Paulo. Do país constitucional ao país neocolonial: a derrubada da Constituição e a recolonização pelo golpe de Estado institucional. 4. ed. São Paulo: Malheiros, 2009.
} 
julgamento sumário, ou sob a restrição aos direitos dos opositores. E esta é uma das tantas lições do nacional-socialismo ${ }^{33}$. Falar é um risco, bem como “fazer-se-em-política". Há que se lembrar que não são poucas as ameaças de morte vindas do bolsonarismo, assim como são muitos os casos de autoexílio - com o agravante de que tratamos de 2020 e não do Al-5. No surto de pandemia, em breve paralelo, a autorização para matar vem do Estado, como nas Filipinas ${ }^{34}$.

Desse ponto de vista, menos psicossocial e mais propriamente político-jurídico, há previsão analítica para retomarmos o tradicional bonapartismo soft $t^{35}$, uma vez que, com ou sem Constituição em vigência efetiva, há um entrechoque inevitável (desde o Federalista) entre liberdade e democracia e o Absolutismo, como concentração de poderes e satisfação de desejos classistas não-republicanos. A justificativa histórica remonta à instituição do monopólio estatal do poder $^{36}$ e não nos permite esquecer de $W_{e b e r}{ }^{37}$ e do próprio cesarismo na forma do Kaiser presidente $^{38}$.

Desse modo, sob as limitações cesaristas de representação delegada ${ }^{39}$, também não soa desproporcional - sob a capa preta do golpe de Estado que infira um “novo" Estado de Sítio ou o aquartelamento do Judiciário no Impeachment de 2016 -, a comparação no uso/abusivo dos meios de poder (contra a Carta Política), de que faz uso e abuso o mesmo referido regime fascista, a contabilizarmos as formas absolutistas de poder. Toda vez que se macula a Carta Política, o fascismo se engrandece.

Novamente, a antítese ao fascismo se ancora na realidade eficaz de instituições democráticas que assegurem o Direito à Consciência - derivado ele mesmo do Direito à Constituição, como fruição integral da Carta Política - e com o duplo benefício de se romper a lógica da exceção, a fim, especialmente, de se dedetizar os campos verde-oliva do fascismo nacional ${ }^{40}$. Tanto é assim, a título de exemplo comparativo, a União Europeia vai acompanhar de perto as medidas de emergência perpetradas na Hungria, o primeiro país a concentrar as

\footnotetext{
33 KRIELE, Martin. Introdução à Teoria do Estado: os fundamentos históricos da legitimidade do Estado Constitucional Democrático. Porto Alegre: Fabris, 2009. p. 450

${ }^{34}$ DUTERTE, Rodrigo. Presidente das Filipinas autoriza policiais a matar quem violar quarentena. Uol, São Paulo, 2 abr. 2020. Disponível em: https://noticias.uol.com.br/internacional/ultimasnoticias/2020/04/02/presidente-das-filipinas-matar-coronavirus.htm. Acesso em: 3 abr. 2020.

${ }^{35}$ LOSURDO, Domenico. Democracia ou bonapartismo: triunfo e decadência do sufrágio universal. Rio de Janeiro: UFRJ, 2004.

36 KRIELE, Martin. Introdução à Teoria do Estado: os fundamentos históricos da legitimidade do Estado Constitucional Democrático. Porto Alegre: Fabris, 2009. p. 450

${ }^{37}$ WEBER, Max. Ensaios de sociologia. Rio de Janeiro: Zahar Editores, 1979.

${ }^{38}$ WEBER, Max. Textos selecionados. 3. ed. São Paulo: Abril Cultural, 1985. (Os Pensadores).

39 WEBER, Max. Textos selecionados. 3. ed. São Paulo: Abril Cultural, 1985. (Os Pensadores).

40 KRIELE, Martin. Introdução à Teoria do Estado: os fundamentos históricos da legitimidade do Estado Constitucional Democrático. Porto Alegre: Fabris, 2009. p. 452.
} 
decisões nas mãos do Executivo, a fim de se verificar se há restrições indevidas aos direitos humanos $^{41}$. A medida de retomada da consciência se erige como uma estratégia de combate ao Estado de Exceção como solução provisória que cada vez mais se coloca como definitiva.

\section{O NÃO-DIREITO COMO MEIO DE EXCEÇÃO}

Para o senso comum marcado pelo "fascismo eterno"42, o Direito (mal posto) é equivalente de uma “excludente de licitude", isto é, na prática vive-se a experiência de que tudo que é ilegal e ilegítimo ressoa como construção jurídica. De fato, o Direito não é um ideal (quando muito uma “ficção"), mas é sobretudo uma realidade substantiva, como realidade substantiva e prática que se emoldura em alicerces - e o primeiro alicerce é o piso histórico em que o próprio conceito se move e se modifica: até mesmo se remove. Desse modo, o Direito é parte inerente de uma “democracia substantiva” - no dizer de Mészáros ${ }^{43}$. Mas também diz-se que o Direito é inerente a qualquer forma de organização política (se aqui incorrêssemos na restrição que trata o Direito como lei), pois tanto o Direito pode ser legítimo e democrático, quanto fascista: a diferença aqui é a inobservância do Direito como equidade, mas simplificado como Estado de não-Direito ${ }^{44}$, ou seja, neste caso, sob o fascismo, sem a prevalência da equidade, não há que se falar da observância do Direito.

A fim de melhor avaliar como isto se arrumaria, temos de partir de premissas: só há Direito como percurso da equidade e da dignidade, uma vez que se entrelaçam liberdade e igualdade (isonomia). Com Mészáros ${ }^{45}$, podemos ver que precisamos de um direito à autonomia: emancipação. Ou o que também chamaremos de Direito à Consciência: o Direito à Consciência é “consciência do próprio Direito à Emancipação" e que decorre, por sua vez, de uma planta jurídica ramificada como descentralização do poder - além da divisão e do controle dos poderes (interno e externo). Em suma, como condição substantiva em que o Direito só pode ser autonomia (auto + nomos).

\footnotetext{
41 PINTO, Ana Estela de Sousa. Sob críticas, UE diz que vai acompanhar medidas de emergência na Hungria. Folha de S. Paulo, São Paulo, $1^{\circ}$ abr. 2020. Disponível em: https://www1.folha.uol.com.br/mundo/2020/04/sob-criticas-ue-diz-que-vai-acompanhar-medidas-deemergencia-na-hungria.shtml. Acesso em: 2 abr. 2020.

42 ECO, Umberto. Fascismo eterno. Rio de Janeiro: Record, 2018.

${ }^{43}$ MÉSZÁROS, István. O século XXI: socialismo ou barbárie? São Paulo: Boitempo, 2003.

${ }^{44}$ CANOTILHO, José Joaquim Gomes. Estado de Direito. Lisboa: Gradiva, 1999.

${ }^{45}$ MÉSZÁROS, István. O século XXI: socialismo ou barbárie? São Paulo: Boitempo, 2003.
} 
Assim, para que não se restrinja ao idealismo jurídico, temos que supor que não há Direito em discordância aos Princípios Gerais do Direito, bem como da realidade formativa do Poder Político e do Direito como expressão social: “Direito e justiça repousam na moral e na opinião, mas, porém, em primeira linha, nas instituições jurídicas e na sua ancoragem inabalável na consciência jurídica do povo"46.

Isto ainda nos ajudaria a entender porque aderimos tão alegremente ao fascismo e ao bolsonarismo, ou seja, porque a opinião pública se baseia em uma determinada moral que é muito ágil em abdicar da justiça, da equidade, da dignidade:

\begin{abstract}
Frases pronunciadas por autoridades públicas valem o quanto pesam e nunca são "da boca para fora". Nenhuma frase pesa tanto quanto aquelas pronunciadas por chefes do Poder Executivo ou candidatos. Como autoridade mais alta de toda uma máquina pública, a demonstração de compromisso com o respeito à lei influencia o comportamento de seus subordinados e de toda a sociedade. Sinais emitidos por um presidente, governador ou prefeito, portanto, não são inofensivos. Sociólogos do direito demonstram a óbvia correlação entre os "sinais e as leis". A liderança da cúpula estatal e das instituições de justiça faz muita diferença para que a lei seja levada a sério. ${ }^{47}$
\end{abstract}

Pois, sem saber o que é Direito, nem distinguir muito bem o certo do errado - no que o povo segue uma parcela grande dos políticos e de alguns representantes do Judiciário nacional -, a todo momento teríamos de reafirmar noções de justiça e do que é o Direito (e do que não é) ainda nas primeiras séries escolares: Direito como consciência da emancipação e como exercício prático da autonomia (auto + nomos).

Afinal: “a mais importante teoria que se extrai do nacional-socialismo prediz: sem o estado jurídico, no qual cada pessoa tem igual prerrogativa de liberdade e respeito à sua dignidade e o qual repousa sobre as instituições da divisão de poderes, dos Direitos Civis e da democracia, tudo é possível - até os campos de extermínio" ${ }^{48}$. A equidade pressupõe a isonomia, é a premissa maior da lógica jurídica da Justiça, e, com isto em mente, podemos entender a condição fundamental aqui assentada nos Direitos Civis, uma vez que, sem equidade não há liberdade, logo, nem todos são iguais perante o poder de extermínio da "lei do mais forte". Exatamente a "lei do mais forte" que seleciona quem vai viver e quem deve morrer.

\footnotetext{
${ }^{46}$ KRIELE, Martin. Introdução à Teoria do Estado: os fundamentos históricos da legitimidade do Estado Constitucional Democrático. Porto Alegre: Fabris, 2009. p. 453

47 MENDES, Conrado Hübner. A política do pânico e circo. In: ABRANCHES, Sérgio et al. Democracia em risco? 22 ensaios sobre o Brasil de hoje. São Paulo: Companhia das Letras, 2019. p.233

${ }^{48}$ KRIELE, Martin. Introdução à Teoria do Estado: os fundamentos históricos da legitimidade do Estado Constitucional Democrático. Porto Alegre: Fabris, 2009. p. 452-453
} 
Por fim, percebe-se que o fascismo primeiro golpeia os Direitos Civis, pois aí estão interligadas a liberdade e a igualdade na cidadania, e os Direitos Políticos, porque é da consciência do "fazer-se política" que se vai ao Direito como emancipação. E é por isso que o fascismo tanto prospera no Brasil, enquanto cultura político-jurídica - porque, abdicando da equidade (liberdade e igualdade), não fabricamos enquanto construção social uma perspectiva massificada de aderência ao Direito (equidade e igualdade: isonomia) e, além disso, não conseguimos distinguir entre fascismo e democracia.

O que, na linha final da exclusão do Direito (da vida civil e das instituiç̧̃̃es de poder) e da cidadania, na ordem prática da vida comum do homem médio, equivale a nivelar toda forma de Estado e de Direito (agora reduzido à lei) à mais comum ou solene negação da dignidade humana. Porque todos os Estados são iguais, como "status", formas e mais formas específicas de organização do poder político destinada à opressão. O povo brasileiro vive isso todo dia, sem dúvida alguma, mas esse problema não é do Direito e sim de sua negação. Hoje, como não se via nos últimos 30 anos de "Nova República", somos fortemente atingidos pelo vigoroso bastão de poder a serviço do antidireito ${ }^{49}$.

\section{O BANÓTICO NORMALIZOU A EXCEÇÃO}

Para muitos de nós, o isolamento provocado pelo novo coronavírus em 2020 trouxe a sensação do mesmo de ontem (e mais uma vez). Utilizando as redes sociais como metáfora para explicar o que estamos alegando, no passado, vigoravam os sistemas chamados de Panópticos de vigilância e controle: prisões, quartéis, conventos e seminários, que Foucault ${ }^{50}$ esclareceu desde a apropriação de corpos à estética das edificações. Uma pessoa se encarregava de vigiar todos os demais, colocando-se bem no centro da edificação e por onde haveria o tráfego normal das pessoas. Hoje, isso ainda existe, mas predomina um outro espectro, muito mais sutil e imperceptível aos bilhões de usuários das tecnologias de comunicação. Chama-se Banótico:

Suas três características são o poder excepcional em sociedades liberais (estados de emergência que se tornam rotineiros), traçar perfis (excluir certos grupos, categorias de pessoas excluídas de forma proativa em função de seu potencial comportamento futuro) e normalizar grupos não excluídos (segundo a crença no livre movimento de bens, capital, informações e pessoas). [...] 0 ban-óptico

\footnotetext{
${ }^{49}$ FILHO, Roberto Lyra. $O$ que é direito. 17. ed. São Paulo: Brasiliense, 2002.

50 FOUCAULT, Michel. Vigiar e punir: nascimento da prisão. Tradução Raquel Ramalhete. Petrópolis: Vozes, 1987.
} 
guarnece as entradas daquelas partes do mundo dentro das quais a vigilância do tipo "faça você mesmo" é suficiente para manter e reproduzir a "ordem"; basicamente, ele barra a entrada a todos os que não possuem nenhuma das ferramentas adequadas para isso (como cartão de crédito ou Blackberry); e que, portanto, não podem ser considerados confiáveis no que se refere à prática dessa vigilância por conta própria. Esses indivíduos (mais precisamente, essas categorias de indivíduos) devem ter "ajuda mecânica", por assim dizer, para se alinhar aos padrões comportamentais dos "espaços defensáveis". Outra tarefa dos dispositivos ban-ópticos, e de não menor gravidade, é identificar prontamente indivíduos que deem sinais de não estar dispostos a se manter na linha ou que planejem quebrar esses padrões obrigatórios. ${ }^{51}$

De certo modo, o Banótico é autoritário, ainda que a autoridade não esteja reduzida a um só indivíduo, mas é uma condição em que há uma banalização da vigilância que forja uma consciência de autovigilância e vigilância do outro pelas pessoas. A mentalidade incutida se desenvolve sem a necessidade de uma pessoa para ditar as imposições de vigilância:

No Banótico ocorre uma banalização da vigilância, como controle absoluto, porque agora se vigia, se exclui, inclui para em seguida excluir, autoexcluir. Cada um é vigilante de si e dos outros, mas a própria tecnologia criada já nasceu com esta marca: vigiar para excluir. A Internet nasceu para apoiar as forças armadas. Hoje, entramos e saímos de grupos, das redes sociais, na mesma velocidade. Banótico tem o exato sentido de banir, de auto banimento, auto exclusão. Como fazemos, muitos de nós, que foram inseridos em grupos do WhatsApp; o Facebook é o primogênito desse processo, pois dirige para nós quem e o que gostamos de ver. As pegadas digitais, as nossas pegadas, selecionam e excluem o que possa divergir.

Por isso, vivemos em bolhas, cercados de "pares"; os "ímpares", os ímpios de nosso desgosto, são automaticamente excluídos ou excluídos por nós, que também nos excluímos de muitos ambientes virtuais destoantes do nosso querer. Há um eterno estado de exílio, introjetado em cada um que faz uso das redes sociais, pois são excludentes e estimulam a auto exclusão: bloqueios. Desse ponto de vista, as redes sociais normalizaram a sensação de viermos em Estado de Sítio, sitiados para não interagir de fato. ${ }^{52}$

O Banótico nas redes sociais acaba, assim como o Estado de Exceção, bloqueando a realidade. Em qualquer que seja o molde de exceção, seja ela qual for, replicamos a mesmice, o apoio incondicional e a sobreposição do eu ao Outro, privilegiando a egoística interface do "eumesmo". O século XXI segue a métrica do narcisismo e no apogeu das sociedades de massa, experimentamos, além da massificação, o egoísmo e a reprodução da nossa cara a cada instante que é registrado na rede. Porém, não só os algoritmos replicam o que queremos como ainda

\footnotetext{
${ }^{51}$ BAUMAN, Zygmunt. Vigilância líquida: diálogos com David Lyon. Tradução Carlos Alberto Medeiros. Rio de Janeiro: Zahar, 2013. p. 46-47

52 MARTINEZ. Vinício Carrilho. Estado de Exílio: normalização da exclusão. Jus, mar. 2020. Disponível em: https://jus.com.br/artigos/80745/estado-de-exilio-a-normalizacao-da-exclusao. Acesso em: 16 mar. 2021.
} 
reproduzimos no anonimato da comunicação "um-você" este perverso efeito de auto exclusão, reprodução do mesmo (que é você, que sou eu "interagindo" com o umbigo tecnológico) e, talvez o pior de tudo, adotando como normalidade da vida civil, através das inferências do big data. Pela normalização da exceção que é fomentada no espaço virtual, vivemos alegremente um estado de exílio. ${ }^{53}$

Como uma bolha, as redes sociais se opõem à ideia de espaço público, promovendo a privatização e a replicação para um outro igual que contenha a mesma opinião política. Este movimento de separação e escolha algorítmica é agente multiplicador das Fake News:

\begin{abstract}
Pois enviamos e recebemos (de volta) a nossa mesmice, o achismo constante, tudo aquilo que se acha "o certo", sem se colocar à prova de contestação. E nisto ainda se arvora o anti-intelectualismo, pois sem embate de ideias e de pressupostos não há debate político e muito menos a construção do conhecimento. Participa-se, no âmbito da política, desse estado de exílio normalizado e normatizado por algoritmos, e por nossa livre e espontânea vontade. Entretanto, colaboramos diariamente pela interdição da oposição política - seja ela qual for. As redes sociais, se assim for permitida uma epistemologia política, ao desagregar o contraditório, faz por ampliar exponencialmente o Princípio do Terceiro Excluído e se (nos) impõe enquanto discurso totalitário: cada um de nós é um déspota (esclarecido ou não) no manejo das redes sociais. De Kybernets, vagamos como replicadores de um único discurso, de preferência que não ultrapasse cinco linhas. Somos portadores do "pensamento único". Adotamos e adoramos tudo isso, ninguém em sã consciência abriria mão de seus clicks diários, nos mesmos lugares em que se esteve ontem, e ninguém se sente refém, aprisionado, em seu casulo, porque vive conectado em seu estado de exílio. Ninguém poderá estranhar quando a democracia acabar, de fato, pois já vivemos o pleno Estado de Sítio - sitiados por adesão e exclusão do diferente. Nosso status político é de autoexílio. ${ }^{54}$
\end{abstract}

Não é de se estranhar que as redes sociais possibilitam a leitura de um projeto totalitário em sua origem e nós somos os peões que rodam essa engrenagem voluntariamente, livremente se disponibilizando para o autoexílio.

Com o acréscimo de que estamos sitiados em nós mesmos, vigilantes de tudo que não seja compatível à mesmice, que seja disfuncional do Narciso que mora em nossas bolhas de consumo e de gostos. Neste Estado de Sítio, nossa função é contribuir voluntariamente com o exílio. Afinal, nós nos exilamos, nos confinamos, seja para não receber qualquer notificação que embarace nossa área de conforto, seja porque se decretou Estado de Emergência na saúde

\footnotetext{
${ }^{53}$ MARTINEZ. Vinício Carrilho. Estado de Exílio: normalização da exclusão. Jus, mar. 2020. Disponível em: https://jus.com.br/artigos/80745/estado-de-exilio-a-normalizacao-da-exclusao. Acesso em: 16 mar. 2021. ${ }^{54}$ MARTINEZ. Vinício Carrilho. Estado de Exílio: normalização da exclusão. Jus, mar. 2020. Disponível em: https://jus.com.br/artigos/80745/estado-de-exilio-a-normalizacao-da-exclusao. Acesso em: 16 mar. 2021.
} 
pública - ou o constitucional(?) Estado de Sítio ${ }^{55}$. O fato é que o Estado de Emergência tem sido utilizado, de forma frequente, como trampolim para se chegar ao Estado de Sítio. A Hungria se adiantou nesse processo, que muito se assemelha às fases ou formas mais acachapantes da Guerra Híbrida, atacando diretamente a liberdade de imprensa, e depois os direitos civis e políticos ${ }^{56}$. 0 discurso tem sido, invariavelmente, simples: abram mão de toda a liberdade e sobrevivam - aqui há referência imediata à COVID-19, como um monumental exercício de engenharia e de experimento social ${ }^{57}$. 0 fascismo chegaria ao plano global, movido por "nova" onda de Guerra Híbrida - movido por tecnocratas e financistas. Há uma reverberação do bonapartismo soft na meca dos EUA, mas com força exponencial de expansão dos marcos e limites fascistas.

O controle identitário a partir dos dados pessoais veiculados nas redes sociais ${ }^{58}$ é gravemente oneroso, politicamente agrava, aprofunda os limites do fascismo no Brasil (e no mundo) em 2020. Tecnicamente, equivale a se utilizar do "Estado de Necessidade" (que não temos na CF88) para fins de se forjar uma brecha "legal" para se concluir em Estado de Sítio Político ${ }^{59}$. Ambos são mecanismos vinculantes do Estado de Exceção, porém, as justificativas e os marcos constituintes, legais, regulatórios, não são iguais, ainda que o funcionamento possa alcançar efeitos similares em algum momento. Na prática, as diferenças entre o Estado de Sítio Político e o Estado de Necessidade (e que deveriam ser de espécie e de gênero) acabaram reduzidas ao grau - no lugar da qualidade, a "quantidade de tempo" em que os direitos fundamentais sofrem de irrestrita mitigação. Enfim, utilizar-se da "pandemia da morte" como desculpa para se avançar o fascismo por meio das redes sociais coloca o país no curso totalitário.

A meca da sociedade de controle, no século XXI, caminha sempre no mesmo rito: “não tenho nada a esconder, portanto, podem vascular meus dados; posso abrir mão da liberdade (privacidade, intimidade) em prol da segurança”. Os equívocos no raciocínio do homem médio

\footnotetext{
${ }^{55}$ MARTINEZ. Vinício Carrilho. Estado de Exílio: normalização da exclusão. Jus, mar. 2020. Disponível em: https://jus.com.br/artigos/80745/estado-de-exilio-a-normalizacao-da-exclusao. Acesso em: 16 mar. 2021. ${ }^{56}$ BENEVIDES, Bruno. Crise do coronavírus vai acelerar onda autoritária, diz cientista política. Folha de $\mathrm{S}$. Paulo, 3 abr. 2020. Disponível em: https://www1.folha.uol.com.br/mundo/2020/04/crise-do-coronavirusvai-acelerar-onda-autoritaria-diz-cientista-politica.shtml?fbclid=IwAR1ROWrGNXmr_nBhU4s8NZXDLb3X4fccMEtd49ZJ8CADkf1Uyol1i7wAcQ. Acesso em: 11 abr. 2020

${ }_{57}$ PROBLEMAS de segurança fecham laboratório de armas biológicas nos EUA. Mundo Positivo, 9 ago. 2019. Disponível em: https://www.mundopositivo.com.br/tecnologia/mundo-tech/problemas-de-segurancafecham-laboratorio-de-armas-biologicas-nos-eua/?fbclid=IwAR1AqkRwvbnduH5gMcOdkmpde6PIKEPZPAvzwqOwySilzNsAKr3FjiY_9U. Acesso em: 14 abr. 2020.

58 DE LUCA, Cristina. Compartilhamento de dados na luta contra Covid-19 pode ameaçar privacidade? Uol, 4 abr. 2020. Disponível em: http://porta23.blogosfera.uol.com.br/2020/04/04/em-tempo-de-covid-19-aetica-no-uso-de-dados-pessoais-e-imprescindivel/. Acesso em: 16 abr. 2020.

${ }^{59}$ MARX, Karl. A Guerra Civil na França. São Paulo: Global, 1986.
} 
aqui são óbvios. Todavia, o principal crime contra a democracia - a partir do Poder Político controlativo - está em confundir deliberadamente segurança pública com segurança nacional. Este efeito de tornar "normal" o controle social chega a tal ponto que os "hostis", todos e todas que hostilizam as ameaças à democracia e à CF88, acabam vitimados como "inimigos públicos". Ou seja, o adversário político do fascismo, que luta pela garantia democrática, é tornado inimigo político e, assim, torna-se a primeira e principal vítima do fascismo nesta era da sociedade de controle.

Como apontado por Dias $^{60}$ em análise pela perspectiva foucaultiana ${ }^{61}$, no Estado brasileiro "arte de governar" - governamentalidade - em matéria de saúde coletiva, ante a dificuldade de uma diretriz coletiva e expressiva alternância de cargos, é de perfomatividade baixa e de inexpressiva articulação com as demais esferas o é uma dificuldade justamente no plano coletivo e nas formas como a política se consolida como uma verdadeira experiência pública. 0 que favorece a desigualdade como característica marcante do neoliberalismo e se coaduna na naturalização da exceção, quando é possível visualizar que o discurso político do Governo se pauta em enaltecer os curados da COVID-19 e solapa a fissura na saúde com altos índices de casos e de mortes.

Conquanto a figura do Estado de Exceção tradicional não tenha usado Giorgio Agamben como um referencial teórico direto - para não adentrar nas discussões que foram travadas ao redor de últimos textos do autor, em especial quando escreveu sobre a emergência imotivada ${ }^{62} \mathrm{e}$ depois fez esclarecimentos em outro texto ${ }^{63}$, bem como por serem usadas variáveis da exceção não se pode deixar de notar que a pandemia serve a um projeto de Estado de Exceção, principalmente quando possibilita o não-direito ${ }^{64}$. A compilação trazida por Wermuth e Morais, nesse sentido, aponta para que as medidas de enfrentamento da emergência sanitária, ainda que tenham o traço da biopolítica, podem ser vistas como uma contribuição para a reconstrução dos vínculos sociais, no ponto em que recuperam a noção agambiana de que "a pandemia do

60 DIAS, Renato Duro. Governamentalidade, biopolítica e vida precária: a pandemia de Covid-19 no Brasil. Revista Eletrônica do Curso de Direito da UFSM, Santa Maria, RS, v. 15, n. 2, p. 1-26, 6 ago. 2020. ISSN 1981-3694. DOI: http://dx.doi.org/10.5902/1981369443634. Disponível em: https://periodicos.ufsm.br/revistadireito/article/view/43634. Acesso em: 21 set. 2020. p. 16.

${ }^{61}$ Ainda que aqui no texto afirmemos que já estamos em uma sociedade de controle, que passou da disciplina que Foucault apontou em Vigiar e Punir.

${ }^{62}$ AGAMBEN, Giorgio. 0 estado de exceção provocado por uma emergência imotivada. Tradução Luisa

Rabolini. Instituto Humanitas UNISINOS, 26 fev. 2020a. Disponível em: http://www.ihu.unisinos.br/78noticias/596584-o-estado-de-excecao-provocado-por-uma-emergencia-imotivada. Acesso em: 21 set. 2020. 63 AGAMBEN, Giorgio. Chiarimenti. Quodlibet, 17 mar. 2020b. Disponível em: https://www.quodlibet.it/giorgio-agamben-chiarimenti. Acesso em: 21 set. 2020.

${ }^{64}$ Metamorfoseado, onde a liberdade individual significa o risco da comunidade. Ou seja, para garantir o liberalismo o negacionismo esconde o efeito da conduta individual na sociedade. 
novo coronavírus expôs ao mundo: nossa solidão no meio da multidão e, ao mesmo tempo, nossa profunda conexão com essa mesma multidão - o caráter político de nossos corpos”65.

Esta é a razão principal de haver crescente normalização da exceção - em todos os moldes e em todas as variáveis -, porque cada internauta é um autoritário por excelência, sem condescendência, sem apelação. Agimos sumariamente.

\section{CONCLUSÃO}

Do Cesarismo ao Kaiser presidente, ainda que em 2020, pela apropriação de todas as tecnologias, há uma forma predatória de orientar o discurso político. A dominação que surge, primeiramente do espaço público tradicional, reflete-se no ambiente virtual e reproduz as características de hegemonia naturalizadas, restringindo as liberdades, deslegitimando indivíduos para o debate e monopolizando a interpretação do próprio Direito. Por isso dizemos que a Constituição sofre erosão em seus valores democráticos.

Monocraticamente, reafirmamos a essência violenta do Direito (Gewalt) e replicamos a essência do Estado de Exceção: a exclusão. Fazemos isso, como dissemos, todos os dias, a qualquer hora, então, se há Estado de Exceção na política, não haverá estranhamento, afinal, participamos e reproduzimos a nomologia excludente e de exceção com absoluta naturalidade. Já somos normatizados para isso, tão cedo se inicie o dia para ler as mensagens que os "grupos" escolhidos e sedimentados por nós mesmos nos enviaram. Cada um em seu "sítio" já partilha do Estado de Sítio. Nossa natureza humana e jurídica é excludente. A base tecnológica é só uma consequência que aprimora a apropriação da realidade de acordo com a "visão de mundo", ou seja, de acordo com os primeiros e primários interesses individuais. Do presente para o futuro, além da normalização política disso que podemos chamar de Estado de Exílio (em analogia ao Estado de Sítio), talvez nem se fale mais disso: de tão normal que venha a se tornar o isolamento social e a exclusão da Política. O crescente afago popular ao autoritarismo e ao fascismo não serão descabidos, e nem incompreensíveis, uma vez que a base tecnológica conformadora da Modernidade Tardia ${ }^{66}$ também formata a estratificação política, com incidência

65 WERMUTH, Maiquel Ângelo Dezordi; BOLZAN DE MORAIS, Jose Luis. Da exceção Agambeniana à constituição planetária de Ferrajoli: desafios impostos pela pandemia do novo coronavírus às categorias jurídico-políticas tradicionais. Revista Eletrônica do Curso de Direito da UFSM, Santa Maria, RS, v. 15, n. 1, p. 1-29, jan./abr. 2020. ISSN 1981-3694. DOI: http://dx.doi.org/10.5902/1981369443057. Disponível em: https://periodicos.ufsm.br/revistadireito/article/view/43057. Acesso em: 21 set. 2020. p. 9, 26.

${ }^{66}$ GIDDENS, Anthony. As consequências da modernidade. São Paulo: Universidade Estadual Paulista, 1991. 
no formato jurídico prevalecente. Somos monocráticos, monotemáticos em plena era da informação.

O Estado de Exílio, portanto, não é outra coisa senão a correspondência ao Estado de Exceção, como antecipação e agudização trazida pelo atual uso/abuso que se faz a partir das redes sociais, tornando-se apenas mais uma condição de possibilidade da normalização da exceção e viabilizando a praxis autoritária.

\section{REFERÊNCIAS}

AGAMBEN, Giorgio. 0 estado de exceção provocado por uma emergência imotivada. Tradução Luisa Rabolini. Instituto Humanitas UNISINOS, 26 fev. 2020a. Disponível em: http://www.ihu.unisinos.br/78-noticias/596584-o-estado-de-excecao-provocado-por-umaemergencia-imotivada. Acesso em: 18 mar. 2020.

AGAMBEN, Giorgio. Chiarimenti. Quodlibet, 17 mar. 2020b. Disponível em: https://www.quodlibet.it/giorgio-agamben-chiarimenti. Acesso em: 18 mar. 2020.

ARENDT, Hannah. O que é política? Tradução Reinaldo Guarany. 3. ed. Rio de Janeiro: Bertrand Brasil, 2002.

BAUDRILLARD, Jean. A transparência do Mal: ensaio sobre os fenômenos extremos. Campinas: Papirus, 1990.

BAUMAN, Zygmunt. Vigilância líquida: diálogos com David Lyon. Tradução Carlos Alberto Medeiros. Rio de Janeiro: Zahar, 2013.

BENEVIDES, Bruno. Crise do coronavírus vai acelerar onda autoritária, diz cientista política. Folha de S. Paulo, São Paulo, 3 abr. 2020. Disponível em: https://www1.folha.uol.com.br/mundo/2020/04/crise-do-coronavirus-vai-acelerar-ondaautoritaria-diz-cientista-politica.shtml?fbclid=IwAR1ROWrGNXmr_nBhU4s8NZXDLb3X4fccMEtd49ZJ8CADkf1Uyol1i7wAcQ. Acesso em: 11 abr. 2020

BENJAMIN, Walter. Crítica da Violência - Crítica do Poder. In BOLLE, Willi (Org.). Documentos de cultura documentos de barbárie: escritos escolhidos. Tradução Celeste H. M. Ribeiro de Sousa et al. São Paulo: Cultrix, 1986. p. 160-176.

BOBBIO, Norberto. Estado, governo, sociedade: para uma teoria geral da política. 3. ed. Rio de Janeiro: Paz e Terra, 1987.

BONAVIDES, Paulo. Do país constitucional ao país neocolonial: a derrubada da Constituição e a recolonização pelo golpe de Estado institucional. 4. ed. São Paulo: Malheiros, 2009.

CANOTILHO, José Joaquim Gomes. Estado de Direito. Lisboa: Gradiva, 1999.

DELEUZE, Gilles. Conversações. Rio de Janeiro: 34, 1992. 
DE LUCA, Cristina. Compartilhamento de dados na luta contra Covid-19 pode ameaçar privacidade? Uol, 4 abr. 2020. Disponível em:

http://porta23.blogosfera.uol.com.br/2020/04/04/em-tempo-de-covid-19-a-etica-no-uso-dedados-pessoais-e-imprescindivel/. Acesso em: 16 abr. 2020.

DIAS, Renato Duro. Governamentalidade, biopolítica e vida precária: a pandemia de Covid-19 no Brasil. Revista Eletrônica do Curso de Direito da UFSM, Santa Maria, RS, v. 15, n. 2, p. 1-26, 6 ago. 2020. ISSN 1981-3694. DOI: http://dx.doi.org/10.5902/1981369443634. Disponível em: https://periodicos.ufsm.br/revistadireito/article/view/43634. Acesso em: 21 set. 2020

DUNKER, Christian Ingo Lenz. Psicologia das massas digitais e análise do sujeito democrático. In: ABRANCHES, Sérgio et al. Democracia em risco? 22 ensaios sobre o Brasil de hoje. São Paulo: Companhia das Letras, 2019.

DUTERTE, Rodrigo. Presidente das Filipinas autoriza policiais a matar quem violar quarentena. Uol, São Paulo, 2 abr. 2020. Disponível em: https://noticias.uol.com.br/internacional/ultimasnoticias/2020/04/02/presidente-das-filipinas-matar-coronavirus.htm. Acesso em: 3 abr. 2020.

ECO, Umberto. Fascismo eterno. Rio de Janeiro: Record, 2018.

FOUCAULT, Michel. Vigiar e punir: nascimento da prisão. Tradução Raquel Ramalhete. Petrópolis: Vozes, 1987.

FRANZ, Kafka. A metamorfose. Tradução Modesto Carone. 14. ed. São Paulo: Companhia das Letras, 1997.

KORYBKO, Andrew. Guerras Híbridas: das revoluções coloridas aos golpes. São Paulo: Expressão Popular, 2018.

KRIELE, Martin. Introdução à Teoria do Estado: os fundamentos históricos da legitimidade do Estado Constitucional Democrático. Porto Alegre: Fabris, 2009.

FILHO, Roberto Lyra. O que é direito. 17. ed. São Paulo: Brasiliense, 2002.

GOETHE, Johann Wolfgang von. Fausto. Belo Horizonte: Itatiaia, 1997.

GOMES, Helton Simões. Um contato de cada vez! WhatsApp impõe novo limite para encaminhar mensagem. Uol, São Paulo, 7 abr. 2020. Disponível em:

https://www.uol.com.br/tilt/noticias/redacao/2020/04/07/um-contato-de-cada-vez-whatsappimpoe-novo-limite-para-encaminhar-

mensagem.htm?utm_source=chrome\&utm_medium=webalert\&utm_campaign=tilt\&fbclid=IwAR2O QllKbkOWgvYvvVIt6Tif4m10jzEY_c1jGc2jPcNBOjb4D8XwWHxoUs. Acesso em: 8 abr. 2020

GRAMSCI, Antonio. Cadernos do cárcere. Rio de Janeiro: Civilização Brasileira, 2000. (Org. Carlos Nelson Coutinho).

GRAMSCI, Antonio. Notas sobre Maquiavelo, sobre la politica y sobre el Estado moderno. Traducción y notas José Arieó. Madrid: Neueva Visión, 1980. 
GIDDENS, Anthony. As consequências da modernidade. São Paulo: Universidade Estadual Paulista, 1991.

KAFKA, Franz. A metamorfose. São Paulo: Companhia das Letras, 1997.

KRIELE, Martin. Introdução à Teoria do Estado: os fundamentos históricos da legitimidade do Estado Constitucional Democrático. Porto Alegre: Fabris, 2009.

LA BOÉTIE, Étienne de. Discurso da servidão voluntária ou o contra um. Comentários: Claude Lefort. Pierre Clastres e Marilena Chauí. Tradução Laymert Garcia dos Santos. São Paulo: Brasiliense, 1999.

LIGUORI, Guido; VOZA, Pasquale. (Org). Dicionário Grasmsciano. São Paulo: Boitempo, 2017.

LOSURDO, Domenico. Democracia ou bonapartismo: triunfo e decadência do sufrágio universal. Rio de Janeiro: UFRJ, 2004.

MANN, Thomas. Carlota em Weimar. Rio de Janeiro: Nova Fronteira, 2000.

MARTINEZ, Vinício Carrilho; SCHERCH, Vinícius Alves. Do bonapartismo à intervenção federal. Revista Jus Navigandi, Teresina, v. 23, n. 5433, maio 2018. ISSN 1518-4862. Disponível em: https://jus.com.br/artigos/64558. Acesso em: 17 abr. 2020.

MARTINEZ, Vinício Carrilho; SCHERCH, Vinícius Alves. Mutação ou transmutação constitucional, o tendencionismo à opinião pública como obstáculo aos Direitos Fundamentais. Revista Juris Poiesis, Rio de Janeiro, v. 23, n. 31, p.174-196, abr. 2020. DOI: https://doi.org/10.5935/24480517.20190062. Disponível em: http://periodicos.estacio.br/index.php/jurispoiesis/article/viewFile/8169/47966748. Acesso em: 18 set. 2020.

MARTINEZ, Vinício Carrilho; SCHERCH, Vinícius Alves. Do bonapartismo à intervenção federal. Gente de Opinião, 4 mar. 2018. Disponível em:

https://www.gentedeopiniao.com.br/colunista/vinicio-carrilho/do-bonapartismo-a-intervencaofederal-por-vinicio-martinez-e-vinicius-scherch. Acesso em: 16 mai. 2021.

MARTINEZ. Vinício Carrilho. Estado de Exílio: normalização da exclusão. Jus, mar. 2020. Disponível em: https://jus.com.br/artigos/80745/estado-de-exilio-a-normalizacao-da-exclusao. Acesso em: 16 mar. 2021.

MARTINEZ, Vinício Carrilho. 0 conceito de carta política na CF/88: freios político-jurídicos ao Estado de não-Direito. Pesquisa de Pós-Doutorado em Ciências Jurídicas. Paraná: Universidade Estadual do Norte do Paraná, 2019a.

MARTINEZ, Vinício Carrilho. Teorias do Estado - Ditadura Inconstitucional: golpe de Estado de 2016, forma-Estado, Tipologias do Estado de Exceção, nomologia da ditadura inconstitucional. Curitiba: CRV, 2019b.

MARTINEZ, Vinício Carrilho. Teorias do Estado: Estado de (Não) Direito: quando há negação da Justiça Social, da democracia popular, dos direitos humanos. São Paulo: Scortecci, 2014. 
MARX, Karl. A Guerra Civil na França. São Paulo: Global, 1986.

MENDES, Conrado Hübner. A política do pânico e circo. In: ABRANCHES, Sérgio et al. Democracia em risco? 22 ensaios sobre o Brasil de hoje. São Paulo: Companhia das Letras, 2019.

MÉSZÁROS, István. O século XXI: socialismo ou barbárie? São Paulo: Boitempo, 2003.

MILLS, Charles Wright. A imaginação sociológica. 2. ed. Rio de Janeiro: Zahar, 1969.

PINTO, Ana Estela de Sousa. Sob críticas, UE diz que vai acompanhar medidas de emergência na Hungria. Folha de S. Paulo, São Paulo, $1^{\circ}$ abr. 2020. Disponível em:

https://www1.folha.uol.com.br/mundo/2020/04/sob-criticas-ue-diz-que-vai-acompanharmedidas-de-emergencia-na-hungria.shtml. Acesso em: 2 abr. 2020.

PROBLEMAS de segurança fecham laboratório de armas biológicas nos EUA. Mundo Positivo, 9 ago. 2019. Disponível em: https: //www.mundopositivo.com.br/tecnologia/mundo-

tech/problemas-de-seguranca-fecham-laboratorio-de-armas-biologicas-nos-

eua/?fbclid=IwAR1AqkR-wvbnduH5gMcOdkmpde6PIKEPZPAvzwqOwySilzNsAKr3FjiY_9U. Acesso em: 14 abr. 2020.

ROUSSEAU, Dominique. França: Os estados de emergência e os perigos de uma nova normalidade. Estadão, 28 mar. 2020. Disponível em:

https://estadodaarte.estadao.com.br/franca-os-estados-de-emergencia-e-os-perigos-de-umanova-normalidade/?fbclid=IwAROlgmnjEQpDo7pe96w4oR6xEgde-

OhMQl_eASOgD6txNgjY9AnH7SJhvlk. Acesso em: 6 abr. 2020

WEBER, Max. Ensaios de sociologia. Rio de Janeiro: Zahar Editores, 1979.

WEBER, Max. Textos selecionados. 3. ed. São Paulo: Abril Cultural, 1985. (Os Pensadores)

WERMUTH, Maiquel Ângelo Dezordi; BOLZAN DE MORAIS, Jose Luis. Da exceção Agambeniana à constituição planetária de Ferrajoli: desafios impostos pela pandemia do novo coronavírus às categorias jurídico-políticas tradicionais. Revista Eletrônica do Curso de Direito da UFSM, Santa Maria, RS, v. 15, n. 1, p. 1-29, jan./abr. 2020. ISSN 1981-3694. DOI: http://dx.doi.org/10.5902/1981369443057. Disponível em: https://periodicos.ufsm.br/revistadireito/article/view/43057. Acesso em: 21 set. 2020.

Recebido em: 12.07.2020 / Aprovado em: 17.09.2020 / Revisões requeridas em: 16.03.2021 / Publicado em: 24.03.2021

\section{COMO FAZER REFERÊNCIA AO ARTIGO (ABNT):}

MARTINEZ, Vinício Carrilho; SCHERCH, Vinícius Alves. A Normalização do Estado de Exceção na Pandemia Coronavírus. Revista Eletrônica do Curso de Direito da UFSM, Santa Maria, RS, v. 15, n. 3, e48127, set./dez. 2020. ISSN 1981-3694. DOI: http://dx.doi.org/10.5902/1981369448127. Disponível em: https://periodicos.ufsm.br/revistadireito/article/view/48127 Acesso em: dia mês. ano.

Direitos autorais 2020 Revista Eletrônica do Curso de Direito da UFSM

Editores responsáveis: Rafael Santos de Oliveira e Angela Araujo da Silveira Espindola

Esta obra está licenciada com uma Licença Creative Commons Atribuição-NãoComercial-SemDerivações 4.0 Internacional. 
ISSN 1981-3694

(DOI): 10.5902/1981369448127

\section{SOBRE OS AUTORES}

\section{VINÍCIO CARRILHO MARTINEZ}

Professor Associado II (Dr.) do Departamento de Educação da Universidade Federal de São Carlos. Pós-Doutor em Ciência Política e em Educação - UNESP/Marília. Possui graduação em Direito (1988) e em Ciências Sociais pela Universidade Estadual Paulista Júlio de Mesquita Filho - UNESP (1989); mestrado em Programa de Pós-Graduactão em Direito pela Faculdade Estadual de Direito do Norte Pioneiro (2005); mestrado em Educação pela Universidade Estadual Paulista Júlio de Mesquita Filho (1996); doutorado em Educação pela Universidade de São Paulo - FEUSP (2001) e doutorado em Ciências Sociais pela Universidade Estadual Paulista Júlio de Mesquita Filho, UNESP-Marília (2010); Pós-Doutorado em Educação, desenvolvido junto ao Departamento de Administração e Supervisão Escolar da UNESP, Campus de Marília; Pós-doutorado em Ciências Sociais pela Universidade Estadual Paulista/Marília . Atualmente é Professor da Universidade Federal de São Carlos - UFSCar; Coordenou MBA em Direito. Foi bolsista de agências financiadoras de pesquisa, por quatro vezes consecutivas. Também foi professor colaborador do programa de Pós-graduação em Ciências Sociais - UNESP/Marília (2005-2006) e professor de programa de mestrado em direito. Tem experiência na área de Educação, ensino de Sociologia Geral e Teorias do Estado, com ênfase em Educação - Sociedade - Estado, atuando principalmente nos seguintes temas: Sociologia Geral, direitos humanos, Educação e Sociedade, Ciências Políticas e Teorias do Estado. Publicou livros, capítulos de livros e inúmeros artigos de caráter científico, nacionais e internacionais. É articulista de jornal regional há 15 anos, com aproximadamente 700 artigos publicados, e também tem uma página pessoal no site Jus Navigandi, referenciado com qualis B-3.

\section{VINÍCIUS ALVES SCHERCH}

Mestre em Ciência Jurídica pela Univrsidade Estadual do Norte do Paraná - UENP (2019). Especialista em Administração Pública pela Unicesumar (2014), em Direito e processo do Trabalho pela Unopar (2015) e em Direito Constitucional Contemporâneo pelo IDCC (2018). Graduado em Gestão Pública pela Unopar (2015) e em Direito pela Faculdade Cristo Rei (2010). Integrante do grupo de pesquisa da Academia Brasileira de Direito Constitucional (2017), Intervenção do Estado na vida das pessoas INTERVEPES (2017), Democracia e Direitos Fundamentais (2018). Tem experiência na área de Direito, com ênfase em Direito Público. Professor de Direito na Universidade Norte do Paraná - UNOPAR. 